\title{
Study on Osmotic Dehydration of Fig Fruit (Ficus carica) Slices Mediated Tray Drying
}

\author{
T. Niranjan*, G. Rajender, Praneeth Reddy, Vivek Reddy, \\ Akhil Kumar and Vamshi Krishna
}

Department of Processing and Food Engineering, College of Agricultural Engineering, Kandi, Sangareddy, Prof. Jayashankar Telangana State Agricultural University, Hyderabad, Telangana, India

*Corresponding author

\begin{abstract}
A B S T R A C T
Keywords

Fig fruit, Osmotic

dehydration, Tray drying,

Sucrose solution, osmotic solution, fruit slices

Article Info

Accepted:

22 May 2018

Available Online:

10 June 2018

Fig fruit (Ficus carica) are the rich source of minerals, vitamins, and fiber. The moisture content of the ripen fig fruit is about 86 percent due to its high moisture content the fig fruit is readily prone to the attack of yeast and mould. In this study the fig fruit were cut in to slices and dehydrated by osmotic dehydration process. This process is preferred over others due to it is an energy intensive process with retention of initial fruit characteristics viz., aroma, texture, colour and nutritional composition. The fig fruits were cut into slices and soaked in sucrose solution of different concentrations $40^{\circ} \mathrm{Brix}, 50^{\circ} \mathrm{Brix}$ and $60^{\circ} \mathrm{Brix}$ at two different temperatures $40^{\circ} \mathrm{C}$ and $50^{\circ} \mathrm{C}$. The slices were soaked for different time durations until the initial moisture content was reduced to $50 \%$. Further it was subjected to tray drying at $60^{\circ} \mathrm{C}$ for 8 hours and the final moisture content was brought to less than $5 \%$ (safe storage moisture content). In the sensory evaluation it was found that the product dried in the $40^{\circ}$ Brix solution at $40^{\circ} \mathrm{C}$ is more acceptable.

\section{Introduction}

Fruits and vegetables are highly perishable commodities. These commodities have significant post-harvest losses. To avoid these losses and to preserve them for longer period, preservation techniques are to be employed. Preservation of fruits and vegetable can be done by various methods, among them; most significant technique is osmotic dehydration. Osmotic dehydration is a drying process for the partially removal of the water from the food material by immersing the food material in some concentrated solution like sucrose or

salt solution through semi permeable membrane the removal of water from lower concentration of solute to higher concentration results in the equilibrium condition in both sides of membrane (Rastogi et al., 1997). The osmotic dehydration is not only remove the water by the pressure difference in the food material and the concentrated product but also prevent the fruit decolouration by enzyme oxidative browning (Contreras and Smyrl, 1981) and aroma, nutritional constituents and flavour compound are retained. Osmotic dehydration is a simple, economical and nondestructive process with least wastage of fruit
\end{abstract}


during processing (Sharma et al., 2003). The osmotic dehydration and stated that osmotic dehydration can be used successfully for $50 \%$ weight reduction in the material and require further drying or processing to enhance the shelf life(Ashok Kumar and Satya, 2014).

Osmotic dehydration is one of the most suitable energy saving methods for the partial removal of water from foods (EbruEroglu and Hasan, 2010). In the osmotic dehydration the water activity of the food material is lowered which will not allow the microorganisms to grow.

Hence, the present study was undertaken to "Study the dehydration of fig fruit slices using osmotic dehydration mediated tray drying "with the following objectives:

To study the effect of temperature on the osmotic dehydration of fig fruit slices.

To study the effect of concentration of osmotic solution on the osmotic dehydration of fig fruit slices.

To study the effect of osmotic soaking time of fig fruit slices on moisture loss and solid gain

\section{Materials and Methods}

\section{Procurement of raw Materials}

Fresh well matured and ripened fig fruits were procured from nearby garden, Sangareddy, Telangana State. These fig fruits were washed with chlorinated water (50ppm) to remove any traces dirt particles. The fruits were cut into slices along its diameter approximately $1.0 \mathrm{~cm}$ thickness using knifes.

The study was conducted with three different sucrose concentrations of $40^{\circ}, 50^{\circ}$ and $60^{\circ}$ brix at two different temperatures 40 and $50^{\circ} \mathrm{C}$ by using hot water bath. These fruit slices were soaked in three different concentric sucrose solutions at two different temperatures until the slices final moisture content reached to half of their initial moisture content.

Fig fruit slices moisture content was measure by using hot air oven method.

The initial moisture content of fruit slices was $86 \% \mathrm{w} / \mathrm{w}$. After soaking in sucrose solutions these slices were kept in tray dryer at temperature of $60^{\circ} \mathrm{C}$ for $8 \mathrm{hrs}$ to obtain dried fruit slices. These dried fig fruit slices were stored in air tight polythene bags for further use. In this study the moisture content of slices and solids gained by slices were determined by using the following formulae at each $4 \mathrm{hrs}$ of soaking time intervals.

Moisture $(\%$ wet basis $)=\frac{\mathrm{M} 2-\mathrm{M} 3}{\mathrm{M} 2-\mathrm{M} 1} \times 100$

Where

$\mathrm{M}_{1}$ - Weight of empty dish.

$\mathrm{M}_{2}$-Weight of dish cum sample before drying. $\mathrm{M}_{3}$ - Weight of dish + sample after drying.

Solid gain $(\mathrm{g} / \mathrm{g})=\frac{(\text { Mf-So })}{\text { So }} \times 100$

Where,

Mf=Final weight of dried sample $(\mathrm{g})$;

So=Initial solid content $(\mathrm{g})$.

\section{Sensory Evaluation}

The sensory evaluation was carried out on nine point Hedonic scale with ' 1 ' being lowest possible value and ' 9 ' being highest possible value. It includes evaluating product quality based on taste, colour, texture and overall acceptability of the dried fig slices as described by Peryac and Giradot (1952). 


\section{Results and Discussion}

Initially, the fig fruit slices were soaked in $40^{\circ}$, $50^{\circ}$ and $60^{\circ}$ brix sucrose solutions at temperature of $40^{\circ} \mathrm{C}$ until the moisture content was reached to approximately $50 \%$ of initial moisture content. The average initial moisture content of the fig slices was obtained as $86 \%$.

The moisture content of fig fruit slices were recorded at each $4 \mathrm{hrs}$ time intervals. The moisture content of fig fruits slices was decreased with increase in soaking time but the rate of moisture loss/removal was decreased with increase in soaking time as shown in Fig.3. The rate of moisture loss increased with increase in osmotic solution concentration.

The moisture content of fig fruit slices was decreased from $86 \%$ to approx. $23 \%$ in 32 hours of soaking at $40^{\circ} \mathrm{C}$. Similarly $23 \%$ moisture content was obtained in soaking time of $28 \mathrm{hrs}$ and $24 \mathrm{hrs}$ for $50^{\circ}$ brix and $60^{\circ}$ brix sucrose solutions respectively.
The similar trends were observed for fig fruit slices treated in $40^{\circ}, 50^{\circ}$ and $60^{\circ}$ brix sucrose solutions at temperature of $50^{\circ} \mathrm{C}$ until the moisture content was reached to approximately $50 \%$ of initial moisture content. The results were depicted in fig. 4.

The time taken to reach moisture content up to approximately $43 \%$ for slices soaked in $40^{\circ}$, $50^{\circ}$ and $60^{\circ}$ brix sucrose solutions at temperature of $50^{\circ} \mathrm{C}$ was recorded as $24 \mathrm{hrs}$, 20 hrs 6 min and 14 hrs 12 min respectively.

From the above values it was said that the loss of moisture was increased with increase of osmotic solution concentration, soaking time and soaking temperature.

As shown in fig. 5, the percentage of solids gained by fig fruit slices was recorded as $24.90 \%$ in 32 hrs soaking time in $40^{\circ}$ brix solution at $40^{\circ} \mathrm{C}$. Similarly \% solids gained by slices was recorded as $24.3 \%$ for $50^{\circ}$ brix solution in 28 hours and $22.3 \%$ for $60^{\circ}$ brix solution in 24 hours.

Fig.1 Freshly harvested fig fruits

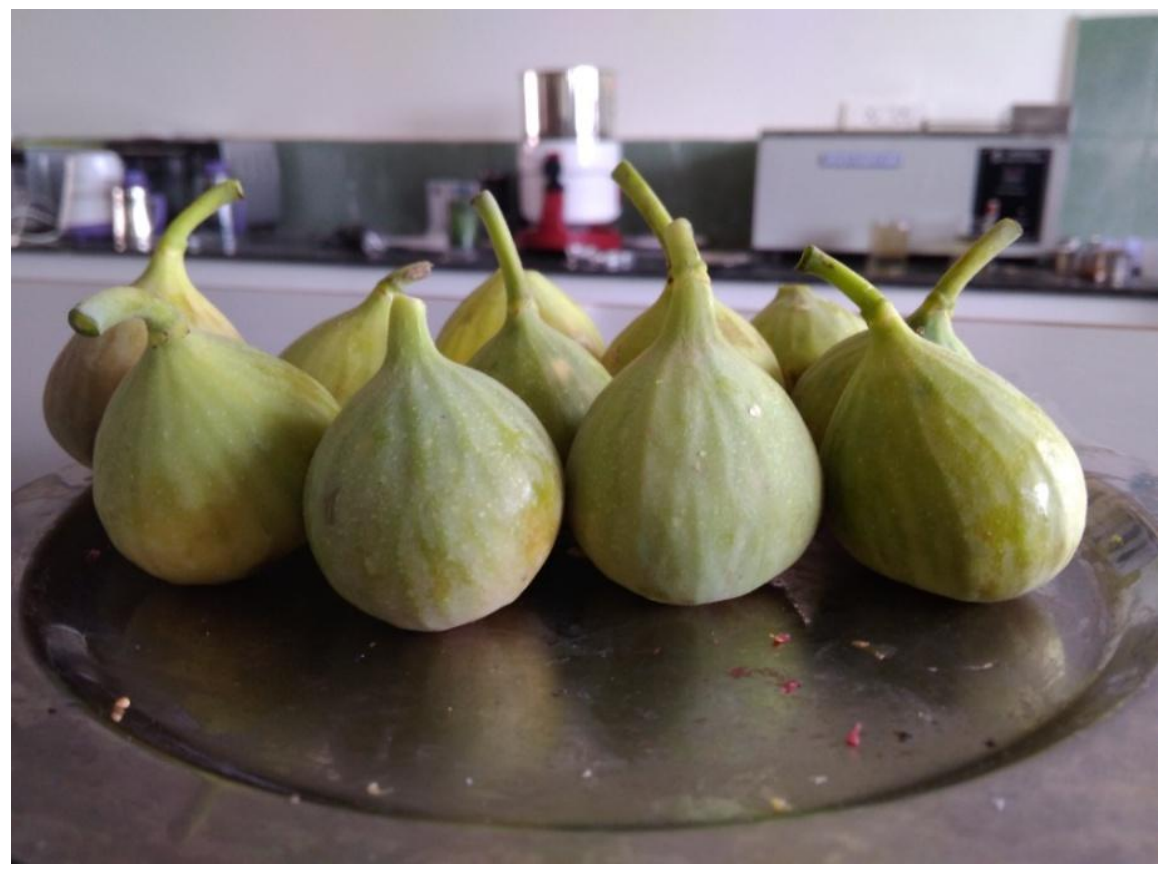


Fig.2 Fig slices in the osmotic solution

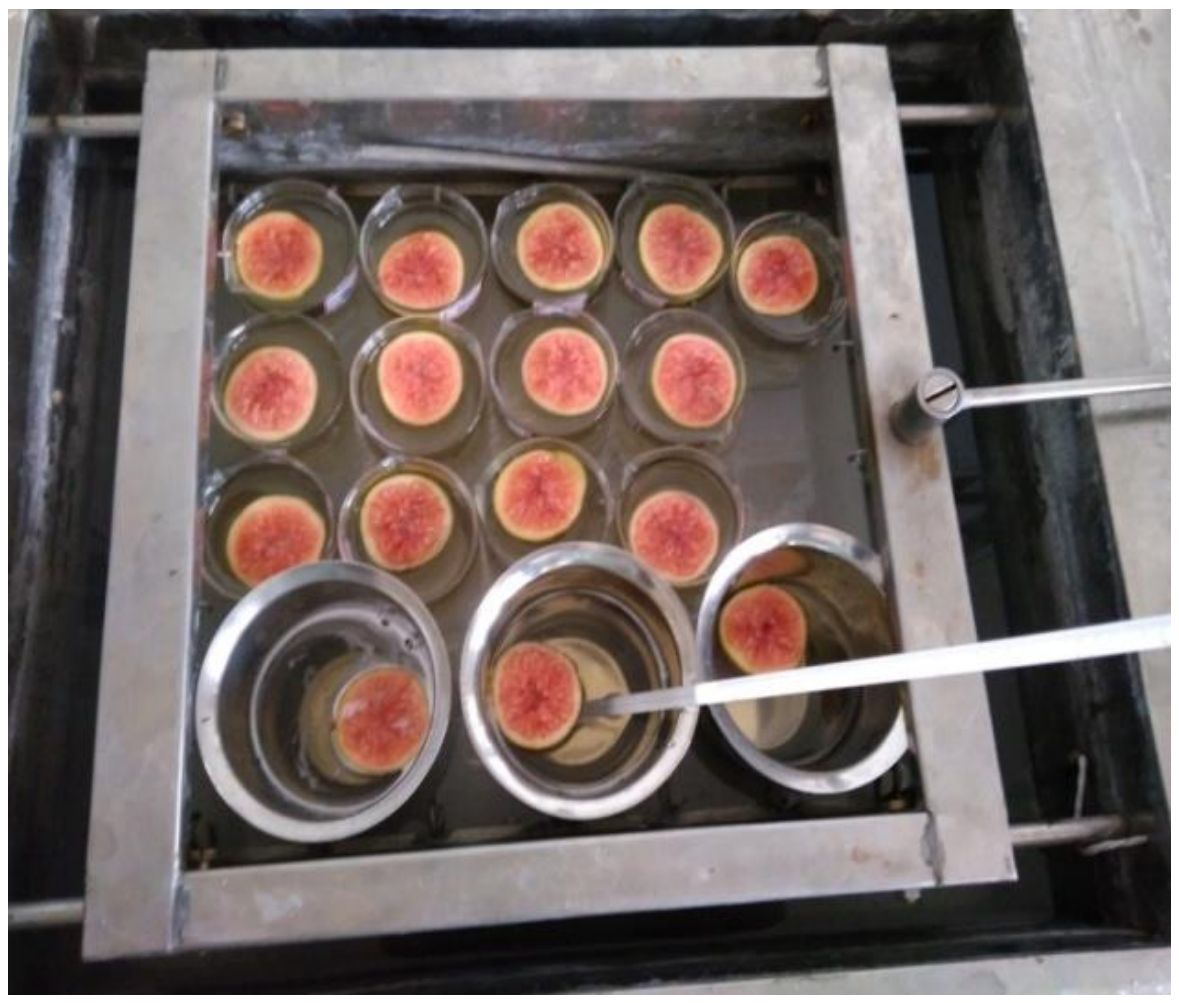

Fig.3 Effect of soaking time on moisture losses of fig slices at $40^{\circ} \mathrm{C}$ in different concentration of osmotic solutions

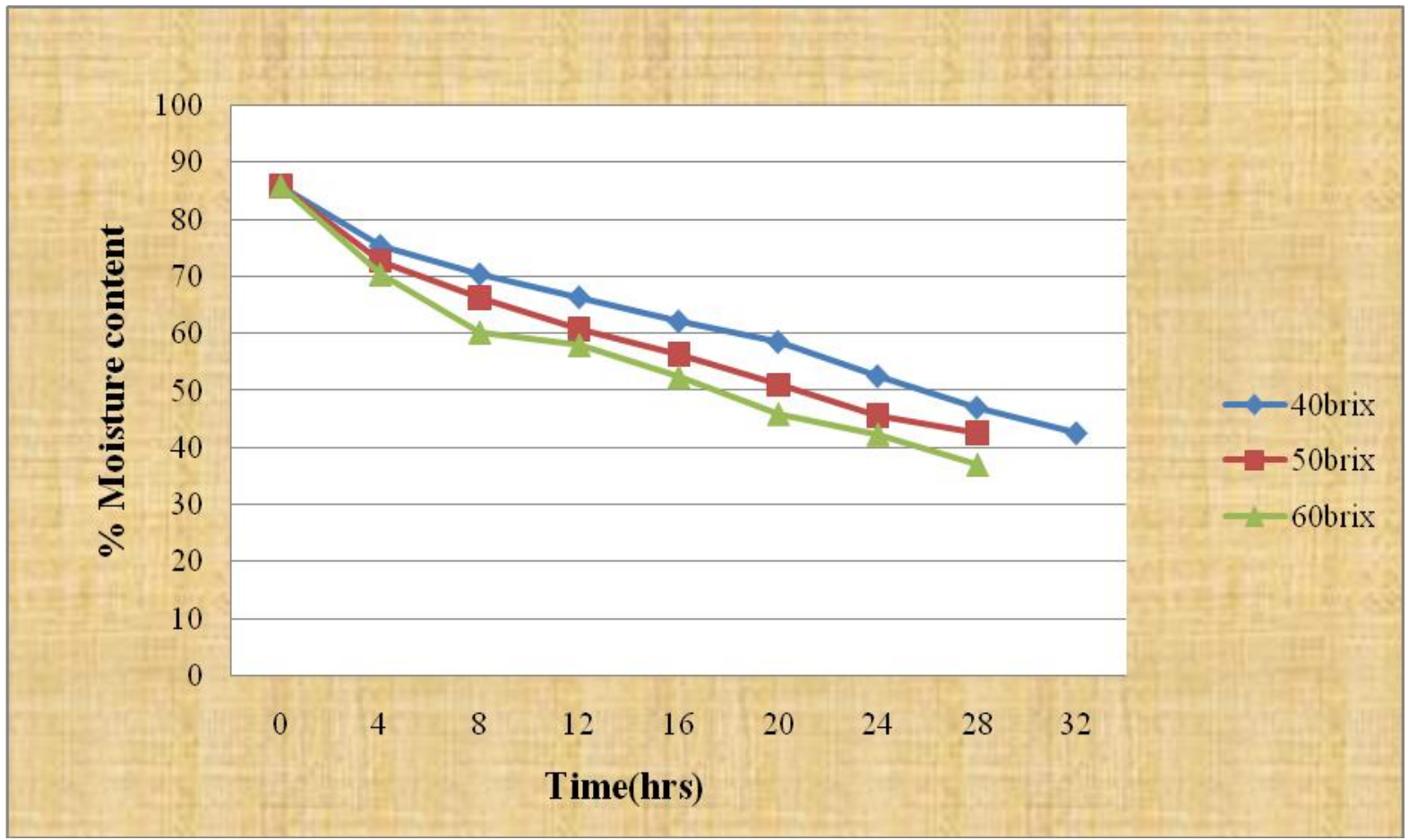


Fig.4 Effect of soaking time on moisture losses of fig slices at $50^{\circ} \mathrm{C}$ in different concentration of osmotic solutions

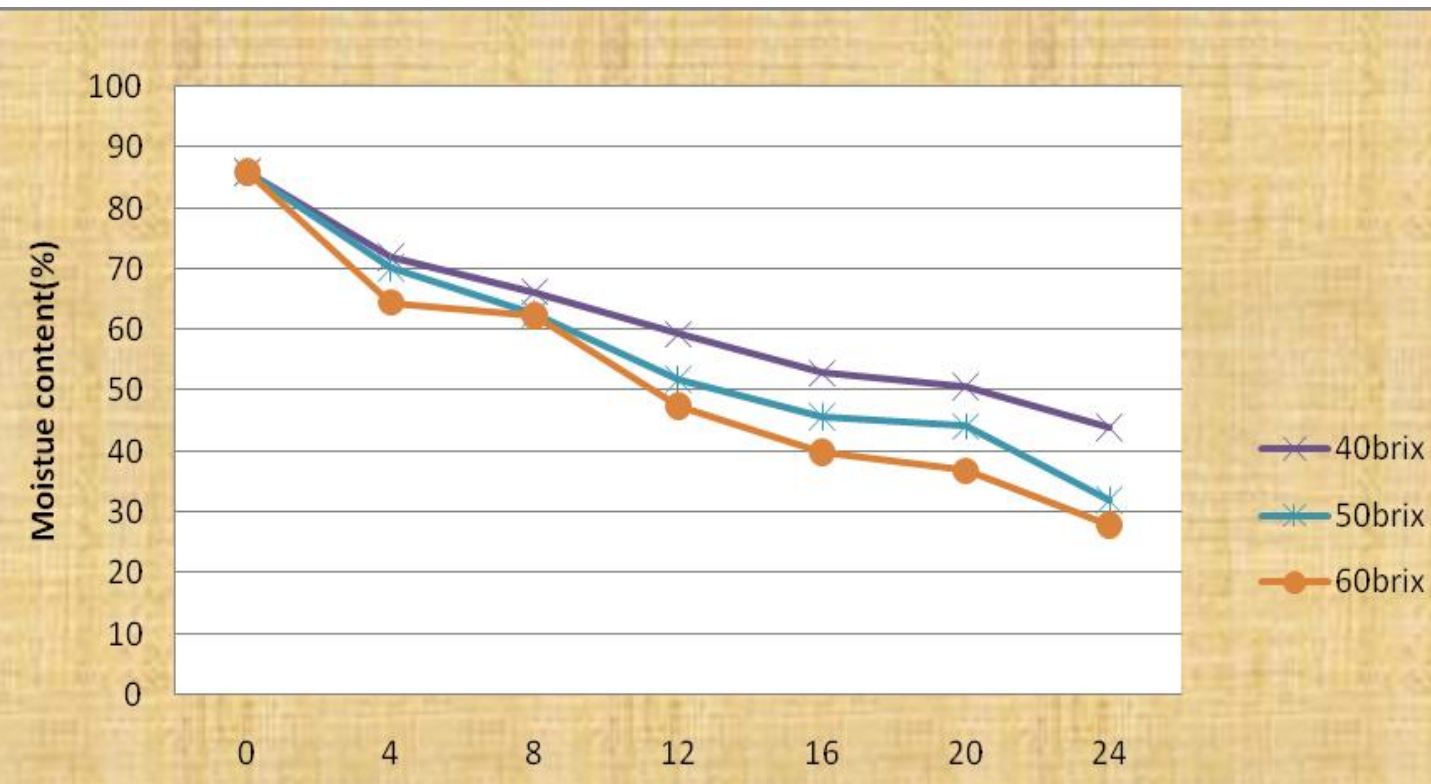

Time(hrs)

Fig.5 Effect of soaking time on solid gain of fig slices at $50^{\circ} \mathrm{C}$ in different osmotic solution concentrations

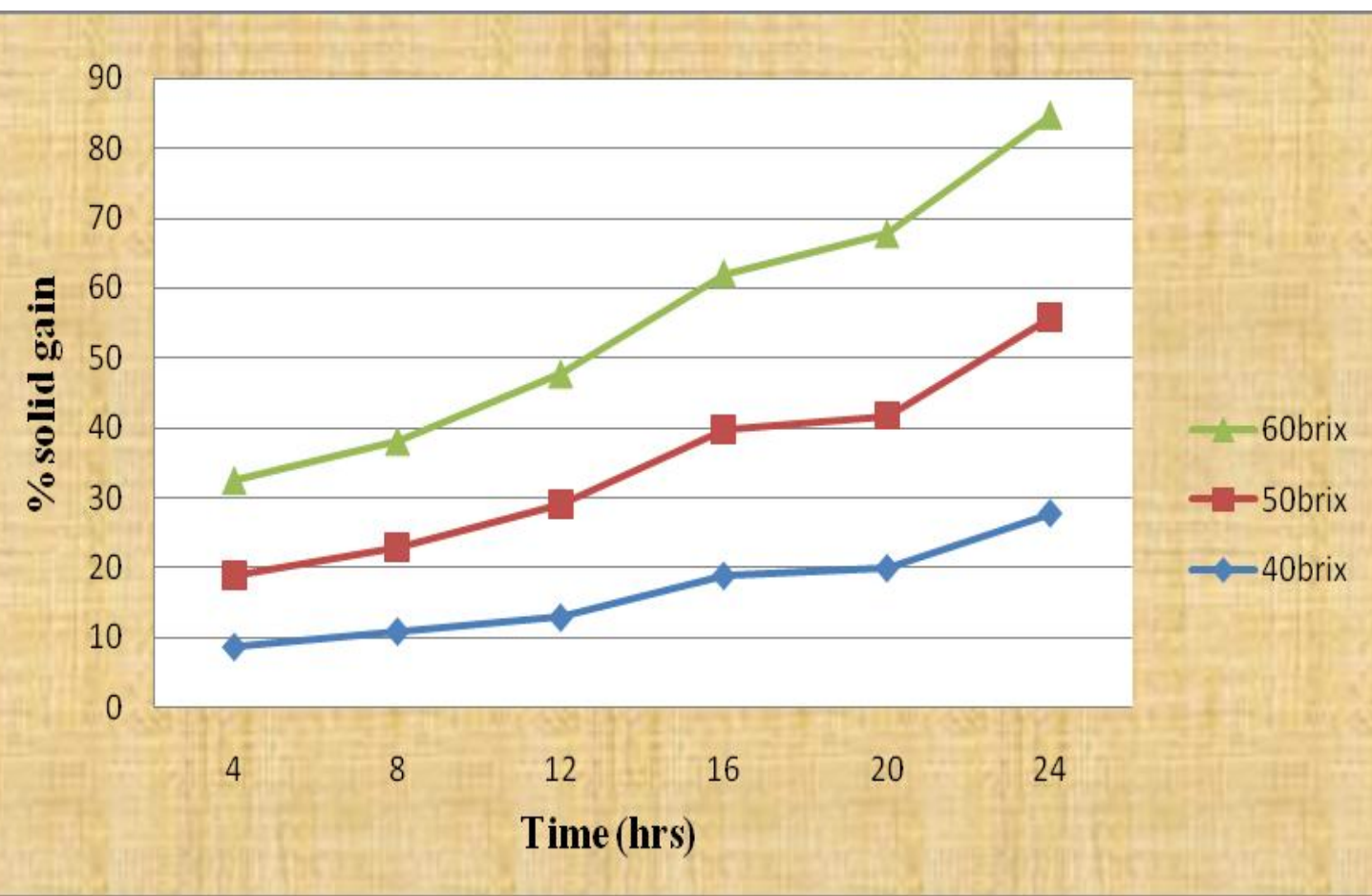


Fig.6 Comparison of sensory attributes of osmotically dehydrated fig fruit slices

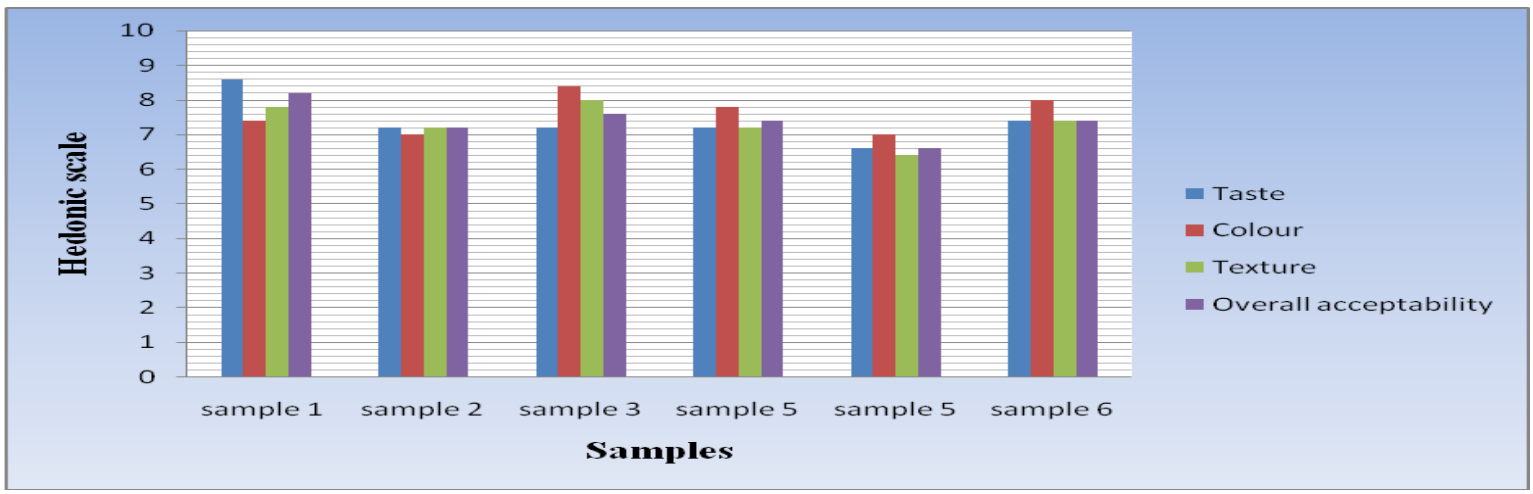

Fig.7 Final product of Fig slices treated in different brix sugar solutions at $40^{0} \mathrm{C}$ mediated tray drying

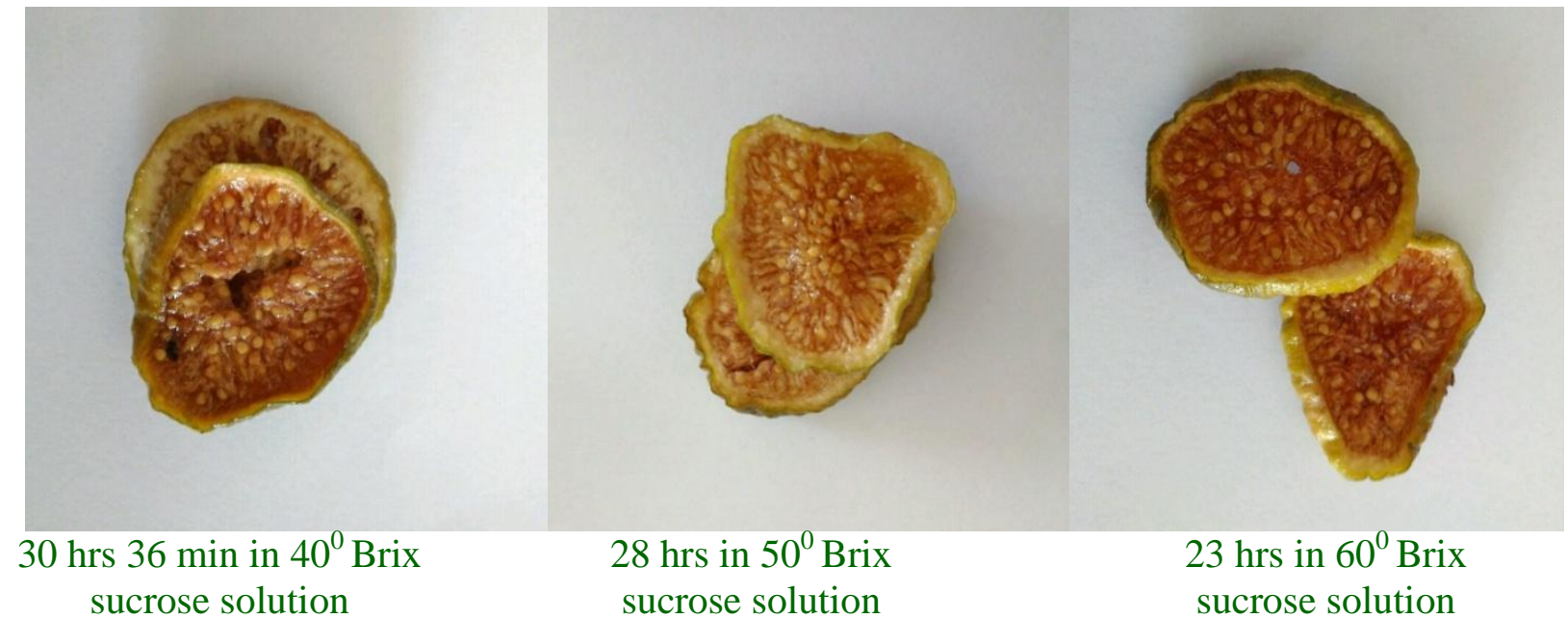

Fig.8 Final product of Fig slices treated in different brix sugar solutions at $50^{\circ} \mathrm{C}$ mediated tray drying

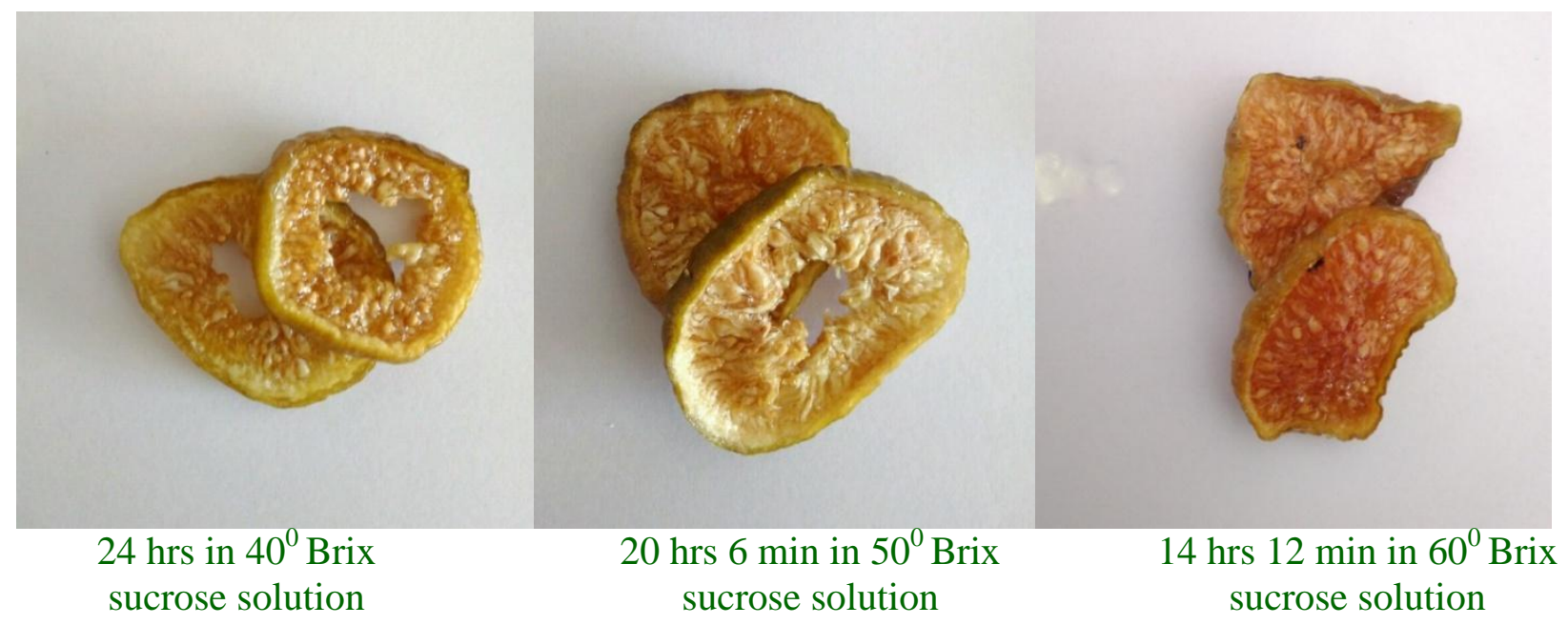


The percentage of solids gained by fig fruit slices was recorded as $27.78 \%$ in $24 \mathrm{hrs}$ soaking time in $40^{\circ}$ brix solution at $40^{\circ} \mathrm{C}$. Similarly \% solids gained by slices was recorded as $21.96 \%$ for $50^{\circ}$ brix solution in 20 hours $6 \mathrm{~min}$ and $20.97 \%$ for $60^{\circ}$ brix solution in $14 \mathrm{hrs} 12 \mathrm{~min}$ as shown in fig.5.

As the degree brix increases from 40 to 60 , the water loss increased with respect to time and temperature. In a similar way, the degree brix increases from 40 to 60 , the percentage of solids gain increased with respect to time and temperature.

\section{Sensory Evaluation}

Sensory evaluation for the osmotically dehydrated fig fruit slices mediate hot air drying at $60^{\circ} \mathrm{C}$ for $8 \mathrm{hrs}$ was conducted using 6 test samples treated at different brix sucrose solutions, time and temperature combinations. The samples numbering was sample1 were the slices treated in 40 brix sucrose solution for $32 \mathrm{hrs}$ at $40^{\circ} \mathrm{C}$, sample 2 were slices treated at 50 brix sucrose solution for $28 \mathrm{hrs}$ at $40^{\circ} \mathrm{C}$; sample 3 were slices treated at 60 brix sucrose solution for $24 \mathrm{hrs}$ at $40^{\circ} \mathrm{C}$, sample 4 were slices treated at 40 brix sucrose solution for $24 \mathrm{hrs}$ at $50^{\circ} \mathrm{C}$, sample 5 were slices treated at 50 brix sucrose solution for $20 \mathrm{hrs} 6 \mathrm{~min}$ at $50^{\circ} \mathrm{C}$, sample 6 were slices treated at 60 brix sucrose solution for $14 \mathrm{hrs}$ $12 \mathrm{~min}$ at $50^{\circ} \mathrm{C}$. These samples were tested with the help of an 8 member panel and the results are furnished in the form of sensory analysis chart.

The highest mean score in taste, colour, texture and acceptability has been recorded for the slices which were treated in $40^{\circ}$ brix sucrose solution for $32 \mathrm{hrs}$ at $40^{\circ} \mathrm{C}$.

The results showed that as the brix increases from $40^{\circ}$ to $60^{\circ}$, the moisture loss increased with respect to time and temperature but rate of moisture loss decreased with respect to soaking time as concentration gradient is decreased. Solid gain increases as concentration of the osmotic solution increases with respect to time and temperature. The slices which are treated with $40^{\circ}$ brix sucrose solution at $40^{\circ} \mathrm{C}$ temperature and then tray drying at $60^{\circ} \mathrm{C}$ for $8 \mathrm{hrs}$ showed the better organoleptic characteristic along with nutritional compounds retention. It was concluded that the optimum brix, time and temperature combination for fig fruit slices was $40^{\circ}$ brix sucrose solutions for $24 \mathrm{hrs}$ at $40^{\circ} \mathrm{C}$ as per the sensory evaluation.

\section{References}

Ashok Kumar Yadav and Satya Vir Singh. 2014. Osmotic dehydration of fruits and vegetables: a review. Food Science and Technology 51(9):1654-1673.

Camila Dalben Madeira, Ana Carla Kawazoe, Renata Valeriano, Míriam Dupas, MíriamDupas. 2012. Effect of process variables on the osmotic dehydration of star-fruit slices. CiêncTecnol Aliment Campinas. 32(2): 357-365.

Contreras, J.E. and T. Smyrl, G. 1981. An evaluation of osmotic concentration of apple rings using com syrup solids solutions. Can. Inst. Food Sci. Technol. J. 14 (4): 310-314

Danila Torreggiani. 1993. Osmotic dehydration in fruit and vegetable processing. Food Research International 26(1):59-68.

Ebru Eroglu, Hasan Yildiz. 2010. Recent Developments in Osmotic Dehydration. Academic Food Journal 8(6): 24-28.

Ela Singh, B. Kalyani, B.Shashank Reddy, P. UshasriKalyani, V. Harika Devi, L. Ravi, M. Shanti., 2015. Study On dehydration of Papaya Slices Using Osmotic Dehydration Mediated Hot Air Oven Drying. IOSR Journal of 
Environmental Science, Toxicology and Food Technology 9(11) II: 72-95.

Fasogbon BM, Gbadamosi SO, Taiwo KA. 2013. Studies on the Osmotic Dehydration and Rehydration Characteristics of Pineapple Slices. Journal of Food Processing \&Technology 4(4): 220.

Insha Zahoor and Khan MA. 2017. Mass Transfer Kinetics of Osmotic Dehydration of Pineapple. Journal of Food Processing \& Technology 8: 263.

Janisiewicz, W.J., Conway, W.S. and Leverentz, B. 1999. Biological control of postharvest decays of apple can prevent growth of Escherichia coli O157:H7 in apple wounds. Journal of Food Protection. 62: 1372-1375.

Lerici, C. R., Pinnavaia, G., Dalla Rosa, M. and Bartolucci, L. 1985. Osmotic dehydration of fruits: influence of osmotic agents on drying behaviour and product quality. Journal of FoodScience 50: 1217-26.

Nanjundaswamy, A. M., Radhakrishnaiah, S. G., Balanchandran, C., Saroja, S. \& Murthy, R. K. B. S. 1978. Studies on development of new categories of dehydrated products from indigenous fruits. Zndiun Food Packer, 1, 91-9.

Owino, W. O., Manabe, Y., Mathooko, F. M., Kubo, Y. and Inaba, A. 2006. Regulatory mechanisms of ethylene biosynthesis in response to various stimuli during maturation and ripening in fig fruit (Ficus carica L.). Plant Physiology and Biochemistry, 44: 33542.
Pan, Y. K., Zhao, L. J., Zhang, Y., Chen, G., Mujumdar, A. S. 2003. Osmotic Dehydration Pretreatment in Drying of Fruits and Vegetables. Drying Technology 21(6): 1101-1114.

Phisut, N., Rattanawedee, M. and Aekkasak, K. 2013. Effect of osmotic dehydration process on the physical, chemical and sensory properties of osmo-dried cantaloupe. International Food Research Journal 20(1): 189-196. Food Science and Technology (Campinas). 36(3): 62-69.

Ponting, J. D., Walters, G. G., Forrey. R. R., Jackson. R. \&Stanley, W. L. 1966. Osmotic dehydration of fruits. FoodTechnology. 20: 125-128.

Rahman, M.S., Lamb, J.1990. Osmotic dehydration of pineappleJournal Food Sci. Technol., 27: 150-152.

Rastogi, N.K., Raghavarao, K.S.M.S., Niranjan, K.1997. Mass transfer during osmotic dehyadration of banana: Fickian diffusion in cylindrical configuration. Journal Food Eng 31(4): 423-432.

Sharma, H.K., Pandey, H., Kumar, P. 2003. Osmotic dehydration of sliced pears. JournalAgricEng 40(1): 65-68.

Suresh Chandra and Durvesh Kumari. 2015. Recent Development in Osmotic Dehydration of Fruit and Vegetables: A Review, Critical Reviews in Food Science and Nutrition, 55: 4, 552-561.

Vinson, J.A. (1999). The functional food properties of figs. Cereal Foods World, $44,82-87$.

\section{How to cite this article:}

Niranjan T., G. Rajender, Praneeth Reddy, Vivek Reddy, Akhil Kumar and Vamshi Krishna. 2018. Study on Osmotic Dehydration of Fig Fruit (Ficus carica) Slices Mediated Tray Drying. Int.J.Curr.Microbiol.App.Sci. 7(06): 3198-3205. doi: https://doi.org/10.20546/ijcmas.2018.706.375 